\title{
ReESCRItas fantásticas E fantasmáticas do "eu" eM Marie NDIAYE ${ }^{1}$
}

Irene Correa de Paula Sayão Cardozo

Universidade Federal Fluminense

\section{Resumo}

Análise das estratégias narrativas empregadas pela francesa Marie NDiaye nos romances Mon coeur à l'étroit e Autoportrait en vert para subverter os modelos da literatura real-naturalista através de diferentes manifestações do insólito. Busca-se mostrar, a partir de reflexões sobre o fantástico, o "estranho" em Freud e o "Real" em Lacan, como os romances resistem à transparência (do "eu" social) visando à parte mais rebelde do sujeito íntimo.

\section{Abstract}

The paper seeks to consider the narrative strategies used by the French writer Marie NDiaye in the fantastics novels Mon Coeur à l'étroit and Autoportrait en vert to subvert the models of real-naturalist literature. It attempts to show, based on reflections about fantastic literature, the Freudian "uncanny" and the Lacanian "Real", how the novels resist the transparence (of the social self) having in sight the most rebellious part of the internal subject (the inner self).

\section{Palavras-chave}

Marie NDiaye, fantástico, alteridade, estranho, psicanálise, autoficção.

\section{Keywords}

Marie NDiaye, fantastic, uncanny, alterity, psychoanalysis, autofiction. 
Se partirmos do pressuposto de que o objeto da literatura é a própria condição humana, o potencial existencial, escrever, ler e estudar literatura pressupõem desvendar e reconhecer o humano e interrogar-se sobre o profundamente íntimo. Segundo o escritor Millan Kundera, ${ }^{1}$ todos os romances de todos os tempos se voltam para "o enigma do sujeito/eu". Desde que você cria um ser imaginário, um personagem, fica automaticamente confrontado com a questão: o que é o eu? Como o eu pode ser apreendido". ${ }^{2}$ Trata-se, segundo ele, de apreender a essência de sua problemática existencial, ${ }^{3}$ já que a literatura examina, para além da realidade, a existência, e a existência não é o que aconteceu, mas o campo das possibilidades humanas, tudo aquilo que o homem pode tornar-se, tudo aquilo de que é capaz. ${ }^{4}$

A literatura fantástica, ao transgredir a realidade cognoscível e permitir a emergência do insólito, do que escapa e resiste às interpretações coerentes e transparentes do mundo (empírico ou subjetivo), revela-se um privilegiado espaço de compreensão dos enigmas do sujeito, na medida em que ultrapassa as fronteiras da verossimilhança, abalando a ordem e a normalidade do mundo. "Espaço de convergências", o fantástico seria, como definiu Julio Cortázar, "um ponto vélico", ${ }^{5}$ um ponto de passagem entre duas ou mais realidades, que permite a percepção de algo habitualmente invisível: "O fantástico força uma crosta aparente, e por isso lembra o ponto vélico; há algo que encosta o ombro para nos tirar dos eixos". ${ }^{6}$

A questão de "como o 'eu' pode ser apreendido", de seu enigma, colocada como central por Kundera na elaboração literária, está, em certo sentido, em consonância com as reflexões de Italo Calvino, sobre o fantástico, já que o autor coloca o "problema da realidade daquilo que se vê" como a essência desta literatura, "cujos melhores efeitos se encontram na oscilação dos níveis de realidade inconciliáveis". Como apreender o que se vê? O mundo, o "eu" são o que aparentam, ou apenas projeções, alucinações fantasmáticas e especulares de nossa mente? O tema do fantástico, como apontou Calvino, seria a relação entre a realidade do mundo que conhecemos por meio da percepção e a realidade do mundo subjetivo, que entrelaçadas produzem, não raramente, o sentimento do insólito, como a irrupção do inconsciente, do reprimido, do que se distanciou da nossa atenção racional. ${ }^{8}$

As obras da autora contemporânea de língua francesa Marie NDiaye ${ }^{9}$ Autorportrait en vert (Autorretrato em verde) e Mon coeur à l'étroit (Coração apertado), ${ }^{10}$ das quais tratarei aqui, revelaram-me, justamente, a transgressora e perturbadora experiência desse algo, inominável e difuso, que emerge como uma irrupção do inconsciente para nos tirar dos eixos. Essa experiência, a meu ver, também se aproxima do que Jacques Lacan ${ }^{11}$ nomeou de "Real"12; trata-se daquilo que não pode ser simbolizado totalmente,

\footnotetext{
${ }^{1}$ KUNDERA, Milan. A arte do romance. Trad. de Teresa Bulhões C. da Fonseca e Vera Mourão. Rio de Janeiro: Nova Fronteira, 1988, p.27.

${ }^{2}$ Ibidem, p.27.

${ }^{3}$ Ibidem, p.32.

${ }^{4}$ Ibidem, p.42.

${ }^{5}$ CORTÁZAR, Julio. "Do sentimento do fantástico". In: Valise de Cronópio. Trad. Davi Arrigucci Jr. e João Alexandre Barbosa. São Paulo: Perspectiva, 2006, p. 179.

${ }^{6}$ Ibidem, p. 175-179.

${ }^{7}$ CALVINO, Italo. "Introdução." In: Contos fantásticos do século XIX. Trad. Maurício Santana Dias. São Paulo: Companhia das Letras, 2004, p.9.

${ }^{8}$ Ibidem, p.9.

${ }^{9}$ A autora nasceu (em 1967) e foi criada na França (em Pithiviers), de uma mãe bretã e um pai senegalês (com o qual teve muito pouca relação). NDiaye recebeu, entre outros, os prêmios Femina em 2001 (por Rosie Carpe), o Goncourt em 2009 (por Trois Femmes Puissantes).

${ }^{10}$ Autoportrait en vert não foi traduzido para o português e Mon coeur à l'étroit (Coração apertado) foi traduzido pela Cosac Naify em 2010. Opto, assim, por manter os títulos em francês.

${ }^{11}$ LACAN, Jacques. «Séminaire XII: RSI». In: Séminaires de Jacques Lacan. Paris: Éditions du Seuil, 1974/1975, p.70-104.

${ }^{12}$ Usarei "Real", com maiúscula, para designar o conceito psicanalítico e "real", com minúscula, para designar a realidade empírica.
} 
porque toca no que há de mais íntimo no sujeito (nos medos, desamparos, faltas e incompletude). O Real não se refere a uma realidade ordenada pelo Simbólico ${ }^{13}$ (representação do mundo exterior), mas existe separado ou fora da linguagem, é o que ainda não foi simbolizado ou resiste à simbolização. Nesse sentido, só aparece nas entrelinhas, nos tropeços ou nos silêncios, emerge na realidade para um lugar onde o sujeito não o encontra (enquanto cogita), a não ser sob a forma de um encontro que o desperte de seu estado ordinário. ${ }^{14} \mathrm{~A}$ literatura pode ser um caminho de acesso ao Real se partirmos do pressuposto de que ela comunica para além do que diz, para além do consciente, despertando sensações e sentimentos inomináveis, tocando no que é indizível e obscuro em cada um (leitor e autor). Transmitir o Real supõe conectar-se com a desordem do inominavelmente secreto. Para Lacan, escrever seria justamente a tentativa de simbolizar os restos não assimiláveis, o "irreproduzível" e assim fazer frente à angústia do Real. ${ }^{15} \mathrm{~A}$ ficção, nesse sentido, aparece como uma espécie de força (crítica) que permite ao escritor "trair" a realidade para só assim poder abordá-la.

Tanto Autorportrait en vert quanto Mon coeur à l'étroit subvertem os modelos da literatura real-naturalista através da manifestação do insólito; o que significa dizer que se elaboram em uma tensão permanente entre realidade e imaginário, natural e sobrenatural. Ambas as narrativas partem de contextos realistas, um cotidiano trivial (verossímil) que vai sendo desfamiliarizado, através de diferentes manifestações estranhas e sobrenaturais. Autoportrait en vert tem a particularidade de mesclar narrativa fantástica e escrita autoficcional ${ }^{16}$ (segundo a própria autora, de um ponto de vista subjetivo, tudo é verdadeiro na obra), propondo-se, assim, a fazer uma reconstituição fictícia e fantástica do "eu".

Trata-se, em ambas as obras, de narrativas que resistem à transparência (do "eu" social) visando à parte mais rebelde do sujeito interno (o "eu” íntimo), seus fantasmas, ${ }^{17}$ delírios e recalques. Temos nos dois romances heroínas-narradoras em primeira pessoa, que possuem uma consciência aguda de sua diferença e vivenciam a experiência de uma crise (uma inadequação com o mundo, com seu próprio ego), que tem como ponto de partida o aparecimento de um evento insólito, que altera suas percepções do mundo e de si. O que se inaugura, a partir daí, é o sentimento da identidade que vacila. As narradoras vivenciam a experiência de um duplo descentramento - do lugar que ocupam no mundo social e cultural e no mundo subjetivo - em decorrência da perda de um "sentido de si", estável e coerente, que provocará uma problematização e "crise de identidade". A identidade somente se torna uma questão quando está em crise, quando algo que se supõe como fixo e coerente é deslocado pela experiência da dúvida e da incerteza. ${ }^{18}$ Assim, colocam-se em cena narradoras com um "eu" caleidoscópico, às voltas com roteiros fantásticos e fantasmáticos (que vão de anuviamentos do "eu” a inusitadas manifestações do insólito), que revelam desejos de relativização e recusa da ordem realista.

\footnotetext{
${ }^{13}$ O Real é definido, para a psicanálise, em relação aos outros dois registros psíquicos: o Simbólico e o Imaginário. O registro do Simbólico pode ser compreendido como o lugar do código da linguagem, do sistema de representações, baseado em significantes. O Imaginário é um registro psíquico correspondente ao ego ("eu") do indivíduo (CHEMAMA, Roland. Dicionário de psicanálise. Trad.Francisco Franke Settineri. Porto Alegre: Artes Médicas, 1995. p. 182).

${ }^{14}$ Ibidem, p.182.

${ }^{15}$ LACAN, Jacques. "Lituraterra". In: Outros escritos. Rio de Janeiro: Jorge Zahar, 2003, p.16.

${ }^{16}$ O termo "autoficção", de autoria de Serge Doubrovsky, entra em cena em 1977 e designa, segundo este autor, uma escrita que estaria entre o real e o ficcional, um entrelugar impossível e inacessível fora da operação do textual.

${ }^{17} \mathrm{O}$ termo "fantasma" (phantasme, em francês) é atualmente utilizado como um conceito para a psicanálise, diferentemente do termo "fantasia", (fantaisie, em francês) em português, que tendem a designar a imaginação de uma maneira geral. Opto pela utilização do termo "fantasma", quando pretendo reforçar o sentido restrito do conceito psicanalítico e do termo "fantasia" quando se trata de imaginação, em seu sentido mais amplo.

${ }^{18}$ HALL, Stuart. A identidade cultural na pós-modernidade. Tradução de Tomaz Tadeu da Silva e Guacira Lopes Louro. Rio de Janeiro: DpeA, 2002, p.9.
} 
Em Mon coeur à l'étroit, Nádia e o marido Ange, respeitados professores de Bordeaux, passam, inexplicavelmente, a ser hostilizados e rejeitados pelos que estão ao seu redor. Suas identidades baseadas na profissão, no respeito e na admiração que inspiram, “desmoronam” subitamente. Nádia começa a inspirar uma estranha repulsa plena de ressentimentos em quase todos que a rodeiam, perde o emprego e vê seu mundo/sua identidade desconstruírem-se. O livro inicia-se, assim, com a constatação de uma mudança, que diz respeito ao "olhar" e à maneira como a narradora acredita estar sendo vista; abruptamente, sua alteridade se revela e ela não é mais vista "como os outros". "Trata-se de um mal entendido?". "Excluídos por quê?”, essa é a pergunta à qual a narradora (e o leitor) procurará responder ao longo do romance. Inexplicável, a princípio, essa transformação se apresentará como um verdadeiro enigma.

A primeira parte começa expressando uma dúvida já em seu título: "Quando tudo começou?" (Quand cela a-t-il commencé?) e termina com a certeza de uma incongruência, que diz respeito a uma incompatibilidade entre duas realidades que estão em contradição: a imagem idealizada que a narradora tem de si mesma (como uma profissional e esposa modelo) e a que o mundo está lhe fornecendo (um ser desprezível, digno de rancor e ódio). É esse desencontro que, de uma maneira geral, produz a estranheza nas obras de NDiaye; um desacordo entre o "eu" e o mundo, que provoca uma sensação de jamais coincidir-se consigo mesmo. A hesitação se instala desde o início, o leitor aguarda uma explicação racional, que justifique as agressões e ostracismo, mas depara-se, em contrapartida, com diferentes acontecimentos inverossímeis, entre os quais: uma insólita e onipresente neblina que modifica a geografia de tudo, a descoberta do "canibalismo" da nora Wilma (vil e má), que teria comido a própria enteada e a gestação e "parto" pela narradora de uma espécie de monstro indescritível.

Autoportrait en vert também cria uma atmosfera de constante mistério através da descrição de inquietantes aparições. O texto é acompanhado por fotos, não menos insólitas, de mulheres e famílias, algumas contemporâneas e difusas e outras de época. A estranheza nasce do desencontro entre o tema, o autorretrato da jovem autora negra NDiaye, e as fotos, de mulheres brancas e famílias do inicio do século XX. Nas bordas do rio Garonne, uma mulher comum leva suas crianças à escola, mas a banalidade do cotidiano é surpreendida por uma aparição que só ela vê, "uma presença verde", ${ }^{19}$ de cor "vegetal e perigosamente feminina", ${ }^{20}$ estranha, fascinante e ambígua. A visão deste espectro, desta "mulher de/ em verde" ("Femme en vert"), surge como uma alucinação, abrindo-lhe irremediavelmente as portas do incognoscível. Essa visão fantasmática-fantasmagórica (que a narradora supõe, mais tarde, pertencer a uma certa Katia Depetiteville, falecida há quinze anos), nunca vista antes (mas que sempre esteve ali), provocará uma série de reminiscências insólitas. Ela marca uma mudança no olhar da narradora; como se "um véu de fulgente irrealidade", ${ }^{21}$ um "filtro verde", tivesse alterado sua percepção da realidade, fazendo-a, finalmente, distinguir o invisível. Como em uma espécie de retorno do recalcado, a narradora revisitará seu passado, sendo capaz de perceber todo o "verde" nele contido e de reconhecer as diversas femmes en vert que aterrorizaram sua vida. Mulheres sádicas, sedutoras ou, simplesmente, desamparadas: sua mãe, "[...] minha mãe é um tipo de mulher de verde que eu jamais encontrei”, 22 "intocável, decepcionante, mutável ao extremo, muito fria"23; uma antiga professora do maternal: "Me vem à mente a inquietante lembrança de uma mulher de verde, do tempo da escola maternal. Aquela grande mulher brutal e

\footnotetext{
${ }^{19}$ NDIAYE, Marie. Autoportrait en vert. Paris: Gallimard/Folio, 2005, p.11.

${ }^{20}$ BARNET, Marie-Claire. « Déroute d'un Autoportrait en vert (mère): vers l'errance de Marie Ndiaye». In: ASIBONG, Andrew e JORDAN Shirley (orgs.). Marie NDiaye: l'étrangeté à l'œuvre. Lilles: Presses Universitaires Charles-deGaulle, 2009, p.166.

${ }^{21}$ Ibidem, p.32: "Un voile de lueur d'irréalité".

${ }^{22}$ Ibidem, p.79: “[...] ma mère est un type de femme en vert d'un genre que je n'ai jamais rencontré".

${ }^{23}$ Ibidem, p.82: “Intouchable, décevante, métamorphosable à l'infini, très froide".
} 
corpulenta nos ameaçava com a prisão se comêssemos lentamente demais ou sujássemos as roupas" ${ }^{24}$; sua ex-melhor amiga, transformada em "mulher de verde" depois de se tornar sua madrasta, e até mesmo o rio Garonne, de águas turvas e imprevisíveis. Mas afinal, “o que são essas mulheres?” é a pergunta que narradora (e leitor) não cessam de fazer, e que remetem à indagação primordial “quem sou eu?". Seriam elas desdobramentos, versões da autora, ela própria uma femme en vert ou, talvez, de sua mère en vert (Mãe de/em verde)? O que simboliza todo esse "verde"?

No caso de Mon coeur à l'étroit, a entrada simbólica no universo fantástico e fantasmático da narradora se dará através de uma "passagem ao ato", uma "fatalidade trágica" e "impossível”: Ange é atacado e ferido gravemente pelos alunos. "Sem motivos, gratuitamente". Essa ferida aberta, que exala "o cheiro da morte" 25 e que ninguém ousa tratar, reatualizará sofrimentos arcaicos, abrindo as portas para o incognoscível. A partir deste ataque, a narradora passa a perceber a realidade que até então parecia sólida e familiar (a casa, o marido, os alunos, os vizinhos) como estranha e perigosa: "Eu reconheço, na sala de estar, na cozinha, a forma familiar do mobiliário, no entanto, é como se eu penetrasse em uma casa estranha, desconhecida, onde um acontecimento trágico houvesse sido causado por um passo em falso da minha parte". ${ }^{26} \mathrm{E}$, principalmente, começa a suspeitar de si mesma, de sua própria identidade, e de que talvez tenha alguma culpa misteriosa em "tudo isso". "O que eu fiz e com quem?". ${ }^{27}$

Ao sair de casa pela primeira vez depois do ataque, Nádia se depara com uma intimidante "atmosfera esbranquiçada", "opacidade leitosa", ${ }^{28}$ "densa, imóvel”, ${ }^{29}$ que transforma a geografia da cidade, as direções das ruas, as distâncias, seus nomes, e parece estar em relação direta e ameaçadora com ela: "Porque imaginar que tudo que me cerca tem uma relação direta comigo [...], não consigo me livrar desta impressão de que a cidade inteira me vigia". ${ }^{30}$ Espécie de véu de irrealidade que se coloca entre ela e o mundo, como uma lente esfumaçada, será responsável por alterar sua percepção do tempo e do espaço: "É por causa dessa pavorosa neblina [...] que nada mais se parece com sua verdadeira fisionomia, Bordeaux não é mais Bordeaux". ${ }^{31}$ É através deste "filtro subjetivo" que distinguirá o inominável.

O "espectro verde" e a "neblina branca" seriam reais ou materializações do medo, da angústia, das narradoras? Fruto da imaginação ou lampejo de insanidade? Na perspectiva de Tzvetan Todorov, ${ }^{32}$ o fantástico dura somente o tempo dessa hesitação, durante a qual o leitor se pergunta se determinado acontecimento no texto é apenas uma ilusão (e o mundo real continua igual) ou se o sobrenatural realmente aconteceu (e o mundo real foi transformado). Ao escolher uma dessas duas opções, deixa-se o fantástico para se entrar em um dos gêneros vizinhos: o estranho, no caso de o leitor admitir que as leis da realidade permanecem intactas e podem explicar o fenômeno aparentemente sobrenatural (através da lógica ou da ciência); ou o maravilhoso, no caso do leitor (e personagem) admitir novas leis da natureza para explicarem o fenômeno; e, neste caso, é a realidade que se revela sobrenatural.

\footnotetext{
${ }^{24}$ Ibidem, p.18: "Me reviens alors l'inquiétant souvenir d'une femme en vert, au temps de l'école maternelle. Cette grande femme brutale et carrée nous promet à tous la prison si nous mangeons trop lentement, si nous salissons nos vêtements". ${ }^{25}$ NDIAYE, Marie. Mon cœur à l'étroit. Paris: Gallimard/Folio, 2007, p.149: "L'odeur de la mort".

${ }^{26}$ Ibidem, p.60: "Je devine, dans le salon, la cuisine, la forme des meubles familiers et c'est, pourtant, comme si je pénétrais dans une demeure inconnue où se serait produit quelque événement tragique causé par un faux pas de ma part ". ${ }^{27}$ Ibidem, p.9 : "Qu'ai-je donc fait et à qui?".

${ }^{28}$ Ibidem, p.149: "Atmosphère blanchâtre", "opacité laiteuse".

${ }^{29}$ Ibidem, p.138 : "Dense, immobile".

${ }^{30}$ Ibidem, p.153: "Pourquoi imaginer que tout ce qui m'entoure a un lien direct avec moi [...], je ne peux me défaire de cette impression que la ville entière me surveille".

${ }^{31}$ Ibidem, p.157: "C'est à cause de cet affreux brouillard, [...] que rien ne ressemble à son vrai visage, Bordeaux n'est plus du tout Bordeaux".

${ }^{32}$ TODOROV, Tzvetan. Introdução à literatura fantástica. Tradução de Maria Clara Correa Castello. São Paulo: Editora Perspectiva, 1975.
} 
A crítica literária Irène Bessière, ${ }^{33}$ em contrapartida, compreende o fantástico não como um gênero, mas um "modo discursivo", uma lógica narrativa que "provoca a incerteza ao exame intelectual, pois coloca em ação dados contraditórios, reunidos segundo uma coerência e uma complementaridade próprias". ${ }^{34}$ Para ela, a simples manifestação do insólito e o sentimento de surpresa ou arbitrariedade do leitor/narrador diante de sua irrupção bastariam para garantir a realização do fantástico. Na perspectiva de Bessière, ${ }^{35}$ o que caracteriza o relato fantástico é a impossibilidade da solução resultante da presença de todas as soluções possíveis:

A explicação do enigma se confunde com esse movimento de regressão que estanca com a descoberta da causa. O fantástico recusa esta regressão; a sequência das explicações não conduz jamais a uma explicação única, cada proposta de solução invoca sua própria explicitação. ${ }^{36}$

Adotando um ponto de vista semelhante, o escritor e teórico boliviano Renato Prada Oropeza, embora defenda que o fantástico deva instaurar a dúvida, acredita não ser necessário provocar a busca por uma solução. O importante seria mostrar a fratura, o objeto tenebroso, sem grandes explicações que venham a restabelecer a ordem realista. Assim sendo, este tipo de narrativa aceitaria essa realidade cindida que criaria um tipo de "sem sentido", ${ }^{37}$ onde transitariam simultaneamente o insólito e o verossímil. Os enigmas presentes nos romances estudados são sentidos como fantásticos, na medida em que sobrepõem e entrelaçam soluções e realidades de natureza distinta, cotidiana e extraordinária, psíquica (invisível) e factual (visível).

Na perspectiva de Sigmund Freud ${ }^{38}$, a hesitação fantástica provoca um sentimento de estranheza porque transita no plano da inquietude psíquica (medo) e intelectual (dúvida); "o estranho é aquela categoria do assustador que remete ao que é conhecido, de velho, e há muito familiar" 39 ; algo que amedronta porque remete ao profundamente íntimo, ao conhecido, mas que foi recalcado para o inconsciente. Ao contrário do maravilhoso, que é suficientemente distante da realidade empírica, o estranho suscita desconforto, justamente, por isso. Partindo desta mesma perspectiva, a psicanalista Martha Mon afirma que a hesitação fantástica representa "um escândalo, uma rachadura, uma irrupção insólita quase insuportável no mundo real" ${ }^{40}$, porque tira o sujeito da realidade onde ele se reconhece e o introduz, por um brevíssimo momento, fora do tempo ${ }^{41}$. Nessa perspectiva, o fantástico seria a relação entre a realidade do mundo que habitamos e a realidade do mundo que habita em nós ${ }^{42}$; assim, acham-se irremediavelmente ligadas irrealidade sobrenatural e realidade psíquica.

Nas obras em questão, o aparecimento do insólito elege como tema fundamental o "retorno do recalcado", algo que ameaça ou apavora, visto que remete a "um saber sobre si", familiar e esquecido.

\footnotetext{
${ }^{33}$ BESSIÈRE, Irène. "O relato fantástico: forma mista do caso e da adivinha". Trad. de Biagio D'Angelo. Revista Fronteiraz, vol. 3, no 3, Setembro/2009. Disponível em: <http://www4.pucsp.br/revistafronteiraz/numeros_anteriores/ n3/download/pdf/revista_fronteiraz_impressao3.pdf $>$. Acesso em: 05 de fev. 2015.

${ }^{34}$ Ibidem, p.2.

${ }^{35}$ Ibidem, p. 12.

${ }^{36}$ Ibidem, p.11.

${ }^{37}$ PRADA OROPEZA, Renato. "El discurso fantástico contemporáneo: tension semántica y efecto estético". Revista Semiosis, Tercera época, vol. 2, $\mathrm{n}^{\mathrm{o}} 3$, Enero-Junio/2006. p. 58.

${ }^{38}$ FREUD, Sigmund. "O estranho". In: Obras Completas de Freud. Trad. Jayme Salomão. Rio de Janeiro: Imago, 1969, p.277.

${ }^{39}$ FREUD, op. cit., p.277.

${ }^{40} \mathrm{MON}$, Martha. "O homem de areia ou o espanto se introduziu em sua vida". In: CONSENTINO, Juan Carlos (org.). O estranho na clínica psicanalítica. Rio de Janeiro: Contra Capa Livraria, 2001. p. 81.

${ }^{41}$ Ibidem, p.81.

${ }^{42}$ Ibidem, p. 77.
} 
Como afirma Freud, ${ }^{43}$ não há recalque que não retorne, rompendo as barreiras da consciência e assumindo diversos disfarces, que transformam os espaços familiares em algo ameaçador. A problemática existencial das narradoras, a "alteridade revelada" de Nádia e o "autorretrato em tom verde-atemorizante" do alterego de NDiaye deixam entrever uma cadeia fantasmática, habitualmente recalcada. De um ponto de vista psicanalítico, os fantasmas, por serem motivo de vergonha, são, na vida real, submetidos à censura e só emergem ao consciente através das entrelinhas - dos sonhos, dos lapsos, de um discurso disforme e lacunar -, sem direito a uma expressão clara e direta. Segundo Freud, o sujeito fala abundantemente do sintoma, mas tem resistência ao falar dos fantasmas, por estes revelarem algo de sádico, de proibido, frequentemente velado, ${ }^{44}$ pois surgem em contradição com os valores considerados como moral e politicamente corretos pelo sujeito e pela sociedade.

Nesse sentido, o "verde", onipresente em Autoportrait en vert, seria a cor do fantasma por excelência, pois tira seu conteúdo de dores veladas e elementos perversos; é o que se teme no outro e que é, ao mesmo tempo, parte de si - "quem pode negar que a maldade gosta, particularmente, de se adornar com todo tipo de verde?". ${ }^{45} \mathrm{O}$ alterego de NDiaye se representa como verde - nem preto (como a cor da pele paterna) nem branco (como a cor da pele materna). Busca, assim, escapar aos essencialismos étnicos, cultivando o direto à estranheza e o respeito pelo inconciliável. Segundo a autora, trata-se de um "eu” estranho, fascinante e contraditório, a exemplo de suas impressões desta cor: "o verde é a cor da prosperidade, da natureza, e ao mesmo tempo, uma cor estranha que traz azar e fascina"46. Penso, nesse sentido, o "espectro", cuja visão a fez ver o "invisível, como uma projeção especular-literária da autora (seu duplo "en vert").

No caso de Nádia, sua problemática existencial central é o sentimento de um desajuste social, de uma alteridade "monstruosa", que foi recalcada, justamente por remeter a sentimentos de culpa e vergonha. O fantástico surge, assim, associado às angústias e fantasmas da exclusão. Segundo Dominique Rabaté, NDiaye cria e estabelece um tipo de "fantástico etnológico", ${ }^{47}$ já que incorpora elementos estranhos, insólitos e sobrenaturais a uma abordagem crítica das relações de força ou poder - entre casais, familiares, grupos sociais, etc. - e faz uma reflexão sobre os sentimentos de marginalização e exclusão decorrentes de uma experiência de alteridade étnica, social ou subjetiva. Em uma perspectiva semelhante, Bessière afirma que o fantástico se constitui sobre o reconhecimento da alteridade absoluta, à qual ele supõe uma racionalidade original, "outra". ${ }^{48}$ Segundo ela, o fantástico

burla a realidade na medida em que identifica o singular com a ruptura da identidade, e a manifestação do insólito com a de uma heterogeneidade, sempre percebida como organizada, como portadora de uma lógica secreta ou desconhecida. ${ }^{49}$

O que descobrimos, ao longo da narrativa, é que Nádia vive uma vida de aparências, todas as suas convicções, valores e a imagem que passou a ter de si mesma são fundados em uma negação da

\footnotetext{
${ }^{43}$ FREUD, op. cit., p.277.

${ }^{44}$ Ibidem, p. 102

${ }^{45}$ NDIAYE, Autoportrait en vert, op. cit., p.25: “Qui peut nier que la méchanceté aime tout particulièrement s'orner de toutes sortes de verts?".

${ }^{46}$ NDIAYE apud BARNET, Marie-Claire. «Déroute d'un Autoportrait en vert (mère): vers l'errance de Marie NDiaye». In : ASIBONG, Andrew e JORDAN Shirley (orgs.). Marie NDiaye: l'étrangeté à l'œuvre. Lilles: Presses Universitaires Charles-de-Gaulle, 2009, p.166: "Le vert est la couleur de la prospérité, de la nature, et en même temps, une couleur étrange qui porte malheur et fascine".

${ }^{47}$ RABATÉ, Dominique. Marie Ndiaye: un livre CD. Paris: Culturesfrance/Textuel, 2008, p.37.

${ }^{48}$ BESSIÈRE, op. cit., p.13.

${ }^{49}$ Ibidem, p.13-14.
} 
origem, que seria, para ela, uma espécie de herança maldita. A narradora, que cresceu em um subúrbio de Bordeaux, casa-se com Ange (um pedagogo de sucesso, de origem francesa e burguesa), passa a viver em um bairro elegante da cidade e, assim, rasura voluntariamente seu passado; fica trinta e cinco anos sem ver os pais e esconde suas existências do atual marido e do filho Ralph. Sintomaticamente, sua origem jamais é nomeada, mas alguns elementos nos permitem fazer certas suposições que nos levariam a crer em uma origem afro-magrebina - comunidade de forte imigração na França devido à colonização e frequente alvo de preconceito. Podemos tomar como exemplo mais emblemático, pois retomado inúmeras vezes, a rejeição ostensiva que a escolha do nome da neta Souhar (de origem árabe) produz na narradora: "terrível"50, "maldito", "monstruoso nome". ${ }^{51}$

Em síntese, o retorno do recalcado só se mostrará possível graças à emergência desses "fantasmas", em sua dupla acepção, psicanalítica e sobrenatural, que se apoderam progressivamente da vida das narradoras. No caso de Nádia, primeiro da casa, depois da cidade e finalmente de seu corpo. A narradora passará por uma verdadeira e inusitada metamorfose física. Nádia engorda a ponto de se tornar obesa, seu ventre cresce estranhamente como se estivesse grávida, apesar de, ao que tudo indica, não estar mais em idade para engravidar. Essa estranha "gestação" culminará no "parto" de uma "coisa" estranha -"coisa negra e fluorescente, fugidia [...] de onde ela poderia ter saído, senão do meu corpo?". ${ }^{52} \mathrm{O}$ parto (ou o aborto) dessa espécie de "monstro impossível de representar" (fantasmático e diabólico) tem a função de liberar a narradora, ao menos parcialmente, do "mal" que tomou conta dela. Esse "nascimento" marcará uma espécie de um "renascimento" simbólico da narradora, que reencontra certa paz. Nádia, durante uma visita ao filho em uma cidadezinha ensolarada e distante (o país de origem?), conhece e aceita a neta Souhar, reencontra os pais que haviam sido "resgatados" de seu subúrbio miserável pelo neto, e volta a morar com eles, que a aceitam sem ressentimento. A Nádia do final do livro está, sem dúvida, mais consciente de si mesma, porém, seu mundo permanece cercado de enigmas, nem tudo se adéqua ao ordinário ou se restabelece em uma ordem realista ideal. Seu filho Ralph, por exemplo, permanece vítima de um inominável "mal" (fruto da crueldade e egoísmo da mãe?) e da canibalesca esposa Wilma. Na mesma medida, nenhuma solução existencial se coloca como definitiva. Trata-se de uma redenção? A ameaçadora neblina que sai de cena no final era real ou um filtro interior? Quem realmente é Nádia: a mulher cruel e diabólica que gerou um "monstro" e negou as origens ou a filha pródiga que retorna? Vítima ou culpada?

Essa "coisa" sombria e amedrontadora, "negra e rápida" 53 , também é descrita em Autoportrait en vert, no entanto, neste caso, não brota de dentro da narradora, ela sequer a vê com nitidez, apenas a vislumbra de relance. "A coisa" inominável, ronda a cidade, é vista por todos como uma "alucinação coletiva", menos pela narradora. O "monstro", enquanto materialização do inominável, mostra, dá forma ao impossível, "ilustrando assim a precariedade da ordem e da norma que dão fundamento à nossa concepção de realidade" ${ }^{54}$ Essa seria, inclusive, a origem da palavra, já que "monstro" e "mostrar" têm a mesma raiz. ${ }^{55}$ Também podemos compreender o aparecimento desse "monstro indescritível" como o de uma realidade que, assim como a ideia de Real, proposta por Lacan, existe separada da linguagem,

\footnotetext{
${ }^{50}$ Ibidem, p.300: "Terrible".

${ }^{51}$ Ibidem, p.310: "Maudit", "monstrueux prénom".

${ }^{52}$ Ibidem, p.373: "Chose noire et luisante, fugitive [...] d'où aurait-elle pu jaillir, sinon de mon corps?".

${ }^{53}$ NDIAYE, Marie. Autoportrait en vert, p.27: "Noir et rapide" .

${ }^{54}$ BATALHA, Cristina. "Literatura fantástica: algumas considerações teóricas". In: R. Let. \& Let., Uberlândia-MG, v.28, n², julho/dezembro/2012. Disponível em: <http://www.seer.ufu.br/index.php/letraseletras/article/viewFile/25877/14232>. Acesso em: 05 de fev. 2015, p.488.

${ }^{55}$ Ibidem, p.488.
} 
resistindo à simbolização, justamente por remeter a um saber profundamente íntimo. Em Mon coeur à l'étroit, Nádia se sente culpada por um "crime" (seu ódio às raízes?), que nunca ocorreu concretamente, a não ser no plano afetivo; a materialização do "monstro" pode ser, nesse sentido, compreendida como a materialização da culpa, que a incriminaria. Assim, sua única saída para se libertar da dor e "da miséria" 56 que nasce do seu interior está em "ver" e tentar simbolizar o inominável, através de um despertar da consciência (que justifique as dores e as punições).

Percebemos, nesse sentido, uma aproximação com o universo kafkiano no que tange a certa inversão de valores aliada a uma crítica social. Como observou Kundera em $A$ arte do romance, ${ }^{57}$ Kafka inverte a lógica habitual, segundo a qual, o erro leva ao castigo, já que o personagem punido não sabe a causa da punição. A punição se mostra tão absurda (insólita e inverossímil no caso da personagem Nádia) que a paz só pode ser encontrada se uma justificativa o for, anteriormente. "Se há punição há culpa" é o que conclui o sujeito que experimenta a exclusão, seja ela social ou étnica; assim, a rejeição e o preconceito transformam o sujeito da alteridade em culpado potencial. Nádia carrega consigo uma culpa que nasce, antes de tudo, do sentimento sempre iminente (que se revela através da irrupção do insólito) de que será castigada, caso sua identidade se revele. Identidade essa sentida como o próprio "mal". Vanessa Besand associa, de forma muito pertinente, Nádia a um personagem trágico, pois a grande característica deste tipo de personagem é de ser ao mesmo tempo inocente e culpado. ${ }^{58}$ Nádia é, nesse sentido, simultaneamente, vítima e carrasco, por um lado, vítima da sociedade e de seu desprezo, por outro, culpada por ter renegado seus pais e sua própria comunidade de origem, tendo, assim, reatualizado com seus pares, os ultrajes sofridos por ela própria.

Em contrapartida a narradora de Autoportrait en vert, se recusará ou será incapaz de "ver", nomear ou justificar a existência do temido "monstro" e o "excesso de realidade/verdade" que representa: "que nome dar a essa coisa?", lhe perguntam os filhos, "não, isso não tem nome na nossa língua”, responde. ${ }^{59}$ Recusa-se, assim, ao restabelecimento da ordem, preferindo manter parte de si inapreensível. Em consonância com essa ideia, há uma passagem importante em que a autora-narradora reflete sobre lugar que as "mulheres de verde", reais e, simultaneamente, criações literárias, ocupam em seu imaginário, e que revela sua renúncia em se inscrever (se realizar) plenamente no mundo real. Tudo se passa durante uma visita à casa das irmãs, que não via há muito tempo, por desinteresse, rejeição ou repugnância. Elas vivem "consoladas, quase estabelecidas" $"$, em um mundo monótono e ordinário. É justamente durante essa visita banal que seu "duplo em verde"-o "espectro" de Katia Depetiville e simultaneamente projeção "espectro-literária" - a abandona, sozinha, frente à realidade. É neste exato momento que ela se questiona se suportaria viver como as irmãs (no mundo real) carregando, só, suas dores e desamparos, sem mergulhar em seu mundo subterrâneo, feito de fantasmas e alucinações.

Me vem à mente o pensamento maudoso, como quem sorve um chá sem gosto naquela pequena cozinha, que a minha visita de caridade a essas duas garotas não valia a perda de Katia Depetiteville. Pois[...] temo tornar-me um ser insensato se todas essas "mulheres de verde" desaparecessem uma após a outra deixando-me na impossibilidade de provar suas existências, minha própria originalidade. Pergunto-me, em seguida, na cozinha bem limpa das minhas irmãs, como tornar suportável uma vida desprovida de mulheres de verde, desdobrando, em planos de fundo, suas siluetas equívocas. Preciso, para atravesar calmamente esses momentos

\footnotetext{
${ }^{56}$ Ibidem, p.373: "La misère qui sort de moi".

${ }^{57}$ KUNDERA, op. cit.

${ }^{58}$ BESSAND, Vanessa. «L'art de l'étrange chez Marie NDiaye». In : BENGSCH, Daniel e RUHE, Cornelia (orgs). Une femme puissante : L'œuvre de Marie NDiaye. Amsterdam/New York, 2013, p.119.

${ }_{59}$ NDIAYE, Autoportrait en vert, op. cit., p.107-108.

${ }^{60}$ Ibidem, p.88: "Consolées presque établies".
} 
de estupor, tédio profundo, apatia e desemparo, lembrar-me de que elas adornam os meus pensamentos, minha vida subterrânea, que elas estão lá, ao mesmo tempo, seres reais e figuras literárias sem as quais a dureza da existência parece raspar pele e carne até os ossos. ${ }^{61}$

A transformação das narradoras é, sobretudo, uma transformação de capacidade de percepção, já que passam a ver o que há de terrível ou de maravilhoso por trás da banalidade do mundo, o que escapa à ordem, às identidades "sólidas", aos paradigmas dominantes, ao mundo como deveria ser. O fantástico autoficcional e etnológico de NDiaye, como na imagem do "ponto velico" proposta por Cortázar, sobrepõe e multiplica os ângulos de percepção, relativizando as convicções e impossibilitando uma apreensão ordinária da realidade. Segundo Rabaté, ${ }^{62}$ a estranha fatalidade que toma os heróis de NDiaye e os singulariza reside, justamente, nesta faculdade que eles têm de não saberem, nem poderem se fundir à massa ou adequarem-se ao ordinário. Vivenciam, em outros termos, uma "resistência do tornar-se", no sentido de uma transgressão da normalidade. $O$ fantástico, como ponderou Bessière, pode mostrar, de forma transparente, essa recusa de uma ordem que é sempre uma mutilação do mundo e do "eu". ${ }^{63}$ O ponto "velico", também pode ser compreendido como a própria literatura de NDiaye, pois é ela que permite a convergência de diferentes lógicas, realidades e interpretações, admitindo a realidade fraturada, de um mundo regido por ambivalências e enigmas potencialmente humanos. É, finalmente, através dela que se vislumbra a possibilidade de se entrever a "fissura", o Real, que se conecta com a desordem do inominavelmente secreto.

Recebido em: 04/08/2015

Aprovado em: 10/11/2015

\footnotetext{
${ }^{61}$ Ibidem, p.88: "Me vient la pensé méchante comme je sirote avec ennui mon thé sans goût dans leur petite cuisine, que ma visite charitable à ses deux filles ne valait pas la perte de Katia Depetiteville. Car [...] je redoute de me considérer moimême comme un être insensé si toutes ces femmes en vert disparaissent l'une après l'autre me laissant dans l'impossibilité de prouver leur existence, ma propre originalité. Je me demande alors, dans la cuisine proprette de mes sœurs, comment trouver supportable une vie dénuée de femmes en vert découpant en arrière plan leur silhouette équivoque. Il me faut, pour traverser calmement ces moments d'hébétude, d'ennui profond, de langueur désemparant, me rappeler qu'elles ornent mes pensées, ma vie souterraine, qu'elles sont là, à la fois être réels et figures littéraires sans lesquelles l'âpreté de l'existence me semble racler peau et chair jusqu'à l'os".

${ }^{62}$ RABATÉ, op. cit., p.37.

${ }^{63}$ BESSIÈRE, op. cit., p.14.
} 